\title{
Development of a Sauce Using Gymnema sylvestre Leaves
}

\author{
O. D. A. N. Perera and P. Pavitha \\ Department of Food Science \& Technology, Faculty of Livestock, Fisheries \& Nutrition, Wayamba University of Sri Lanka, \\ Makandura, Gonawila, Sri Lanka \\ Correspondence should be addressed to O. D. A. N. Perera; aannpp2003@yahoo.co.uk
}

Received 22 February 2017; Accepted 19 March 2017; Published 26 April 2017

Academic Editor: Vassiliki Oreopoulou

Copyright (C) 2017 O. D. A. N. Perera and P. Pavitha. This is an open access article distributed under the Creative Commons Attribution License, which permits unrestricted use, distribution, and reproduction in any medium, provided the original work is properly cited.

\begin{abstract}
Plant derived products have attracted enormous attention due to their diverse range of biological and therapeutic properties. Gymnema sylvestre is an underutilized medicinal herb that is widely distributed in different parts of the world. It is rich in phytochemicals with antidiabetic and antiobesity properties; however, it is less popular due to its bitter taste. This study was focused on developing a sauce using leaves of Gymnema sylvestre. The most acceptable composition $(17.2 \%$ water, $4.8 \%$ vinegar, $3.2 \%$ sweet potato, $2.6 \%$ chili, $2.0 \%$ sugar, $2.0 \%$ cinnamon, $2.0 \%$ cardamom, $1.8 \%$ ginger, $1.8 \%$ garlic, $1.2 \%$ onion, $1.2 \%$ salt, $0.1 \%$ citric acid, and $0.1 \%$ sodium benzoate) of the sauce was with $60 \%$ leaf extract. Final product contains $73.54 \% \pm 1.68$ moisture, $19.92 \% \pm 2.59$ carbohydrate, $2.98 \% \pm 0.44$ ash, $2.61 \% \pm 0.58$ protein, $0.88 \% \pm 0.05$ fiber, and $0.05 \% \pm 0.01$ fat. The total flavonoid content was 243.67 $\pm 8.57 \mu$ moles of rutin equivalent, total phenolic content was $65.44 \pm 0.51 \mu$ moles of gallic acid equivalent, and \% of inhibition of $\mathrm{DPPH}$ of total antioxidant capacity was $43.70 \pm 0.72$. Sauce formulated with $1000 \mathrm{ppm}$ sodium benzoate had six weeks of shelf life. The results showed that development of a sauce from G. sylvestre leaves is an effective way of delivering the health benefits to the potential consumers.
\end{abstract}

\section{Introduction}

Currently, people are looking for a quick, easy, and convenient food. Therefore, fast foods are in high demand. Sauce is a more popular food product among people due to the increased consumption of fast food. It is one of the instant side dishes which is used for dipping or used as a condiment. Mostly, sauces are with low nutritional value and high sodium and calorie content. High consumption of fast food leads to health problems $[1,2]$. Vast evidence indicates that a plant based diet can reduce the risk of chronic diseases and promotes sound human health, with functional foods containing physiologically active components [3].

G. sylvestre is a dicotyledonous medicinal herb belonging to the family Asclepiadaceae which is known as "Masbadda" in Sinhala and "Chirukurinja" in Tamil $[4,5]$. It is well known for its sweet taste suppressing activity and is found to be useful for the treatment of diabetes mellitus and obesity [6,7]. It is used as a stomachic, diuretic, inhibited absorption of glucose in the small intestine and has inhibitory action against glucan synthesis and has antieruodonic and antiviral effect [8-10].
G. sylvestre leaves have several functional properties but direct consumption is challenging due to the bitter and astringent taste and these plant based products are lacking in the market [11]. Therefore, this study was focused on developing novel functional food product from G. sylvestre leaves, mainly to supply the health benefit to fast food consumers.

\section{Materials and Methodology}

This study was conducted in four phases. At the first phase, four sauce formulations were prepared by changing the concentration of leaf extract as 50,60, 70, and 80\% (w/w). At the second phase, two sauce formulations were developed by changing the thickening agents to sweet potato flour and pumpkin flour. Finally, sauce formulation was prepared and physicochemical characteristics were evaluated.

2.1. Preparation of Sauce. Initially, prepared leaf extract was boiled with continuous stirring at 55 to $60^{\circ} \mathrm{C}$ for 2 to 3 minutes. Then sweet potato flour was added to the leaf extract 
and heated up to $65^{\circ} \mathrm{C}$ with continuous stirring. Subsequently salt, sugar, vinegar, citric acid, and spices were added and mixed while boiling. Lastly, sodium benzoate (1000 ppm) was added. The final mix was boiled at 65 to $70^{\circ} \mathrm{C}$ with stirring until reaching $25^{\circ}$ Brix. Then, it was immediately transferred into sterilized clean glass bottles and stored at room temperature.

2.2. Sensory Evaluation. Sensory evaluation was done by simple ranking test with five-point hedonic scale. The sensory attributes (color, odor, taste, appearance, texture, and overall acceptability) were evaluated by untrained panel comprising 15 panelists.

2.3. Proximate Analysis. To determine the nutritional content of sauce and leaves, the proximate composition, moisture, ash, fat, protein, total fiber, and carbohydrate content [12], was evaluated.

2.4. Functional Properties. Phenolic content, flavonoids, and antioxidant capacity were determined in leaves and sauce by Folin-Ciocalteu reagent method, aluminium chloride method, and DPPH free radical scavenging activity, respectively $[13,14]$.

2.5. Shelf Life Evaluation. To determine the storage stability of sauce titratable acidity, $\mathrm{pH}$, water activity, and Brix were analysed as physicochemical characteristics at weekly intervals for six weeks [12]. Total plate count and yeast and mold count were also evaluated.

2.6. Statistical Analysis. Nonparametric tests were used to analyse the sensory evaluation. Significant differences between the results were calculated by analysis of variance with the help of Minitab software and SPSS software.

\section{Results and Discussion}

3.1. Sensory Evaluation. Sensory evaluation results revealed the selection of the best leaf extract and thickening agent. First, sensory evaluation was done for the selection of appropriate leaf extract; Figure 1 shows that $60 \%$ extract formulated sauce has scored the highest median score for overall acceptability. Color of the sauce has increased with increasing leaf extract due to the increase of chlorophyll content but consumer's preference for the odor and taste of the sauce has decreased with increasing leaf extract due to the bitterness and astringent taste of G. sylvestre leaves. Therefore, $60 \%$ leaf extract was effective for preparation of sauce.

Most sauces are thickened with starchy products like flour, corn starch, arrow root, bread crumbs, potato starch, and rice flour [15]. Some commercial products used other kinds of starches for thickening [15]. Figure 2 shows second sensory result which reveals that sauce containing sweet potato flour as a thickening agent had highest median score for all the sensory attributes except taste. Therefore, sweet potato flour was selected as the best thickening agent for the sauce formulation. In this study, natural food ingredients

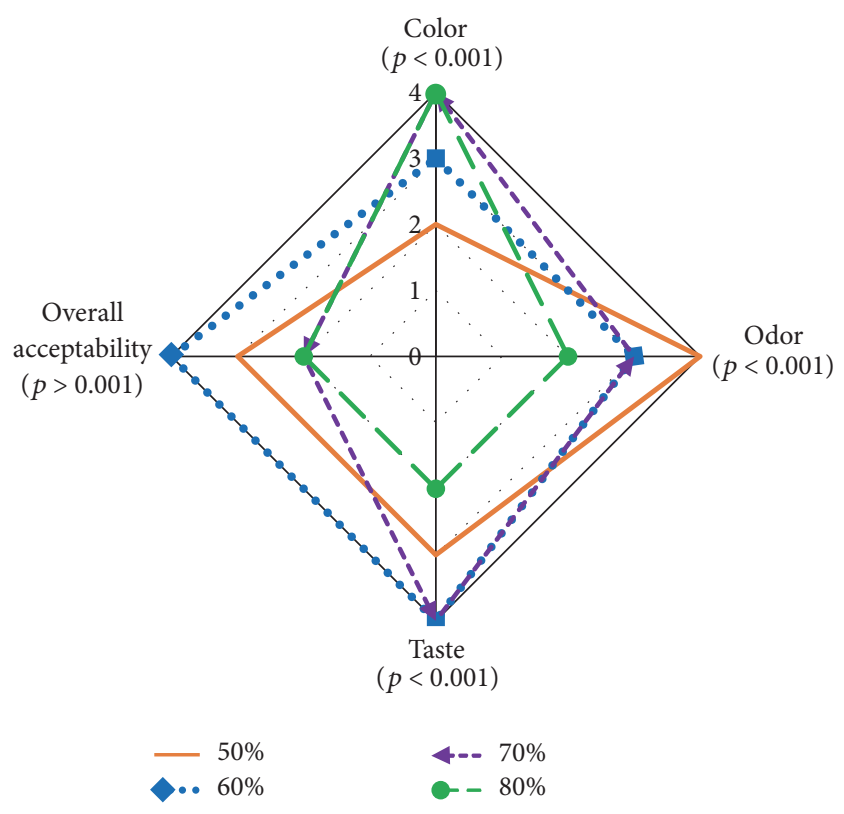

FIGURE 1: Spider web analysis of sensory attributes for sauce containing leaf extracts.

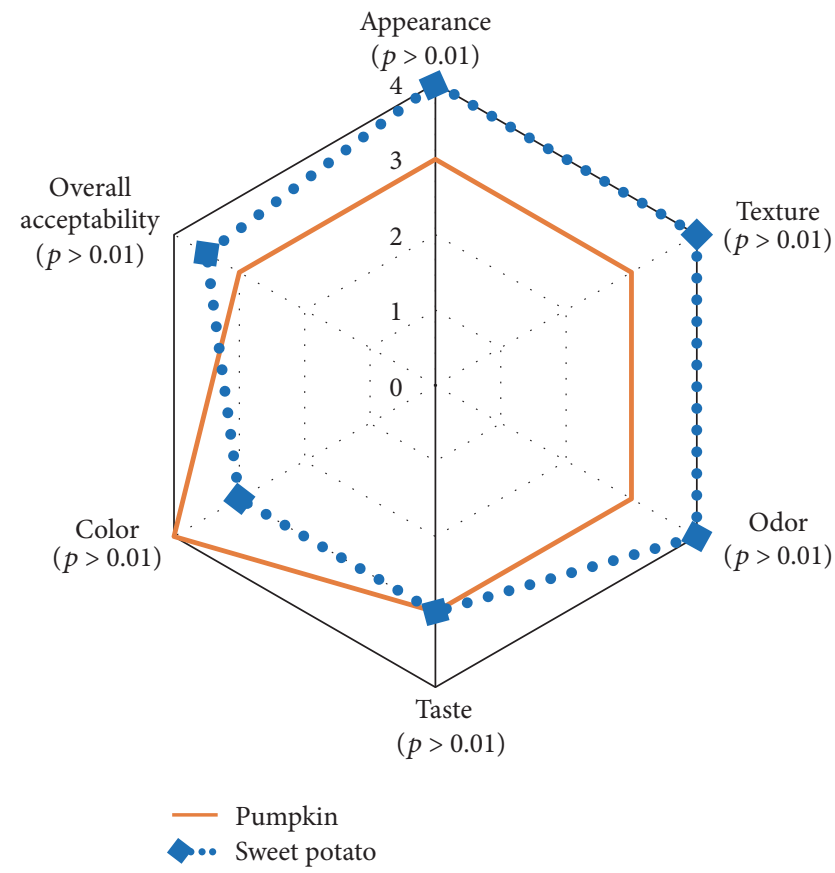

Figure 2: Spider web analysis of sensory attributes for sauce containing thickening agents.

have been used as thickening agents, which is an effective way of incorporating beneficial constituents. Consumption of sweet potato provides pharmacological investigations on the antidiabetic, antihypertensive, anti- inflammatory, antimicrobial, and antioxidant activity $[16,17]$.

After sensory evaluation, by using sensory results, the final formulation of $G$. sylvestre sauce was prepared, which contains $60 \%$ extract, $17.2 \%$ water, $4.8 \%$ vinegar, $3.2 \%$ sweet 
TABLE 1: The proximate composition of the G. sylvestre leaves and sauce product.

\begin{tabular}{lcc}
\hline \multirow{2}{*}{ Proximate value } & \multicolumn{2}{c}{ Amount $(\mathrm{g} / 100 \mathrm{~g}$ wet basis) } \\
& G. sylvestre leaves & Sauce \\
\hline Moisture & $79.69 \pm 1.78$ & $73.54 \pm 1.68$ \\
Total solids & $20.31 \pm 1.78$ & $26.45 \pm 1.68$ \\
Carbohydrate & $7.17 \pm 2.44$ & $19.92 \pm 2.59$ \\
Crude protein & $10.29 \pm 0.76$ & $2.61 \pm 0.58$ \\
Ash & $2.04 \pm 0.80$ & $2.98 \pm 0.44$ \\
Crude fiber & $0.29 \pm 0.01$ & $0.88 \pm 0.04$ \\
Crude fat & $0.50 \pm 0.14$ & $0.05 \pm 0.01$ \\
\hline
\end{tabular}

The values are Mean \pm SD of three independent determinations.

potato, $2.6 \%$ chili, $2.0 \%$ sugar, $2.0 \%$ cinnamon, $2.0 \%$ cardamom, $1.8 \%$ ginger, $1.8 \%$ garlic, $1.2 \%$ onion, $1.2 \%$ salt, $0.1 \%$ citric acid, and $0.1 \%$ sodium benzoate.

3.2. Proximate Analysis. Proximate composition was done to determine the nutritional value of sauce which is shown in Table 1 . There was significantly $(p<0.05)$ high amount of moisture content in G. sylvestre leaves compared to sauce. In comparison, moisture content of tomato sauce is 66.65 \pm 0.14 [18] lower than G. sylvestre sauce because tomato pulp contains higher amount of total solids than leaf extract. Sauce is generally considered as low fat product; however, $G$. sylvestre sauce has very small amount of fat compared to other sauces (tomato sauce contains $0.62 \pm 0.01 \mathrm{fat}$ ) [18].

3.3. Functional Properties. Phytochemicals are rich in plant species; therefore plant derived products are considered as functional foods [3]. From Table 2, it has been demonstrated that sauce has high phenolic content and antioxidants compared to its leaf counterpart. In processing of sauce, several ingredients are added, cinnamon, cardamom, ginger, garlic, onion, and sweet potato, which are rich sources of antioxidants due to the presence of various phenolic compounds [19]. The processing methods such as blending and heating may cause enhancing the phenolic content via increasing softening of the tissues and liberating the bound phenolic compounds present in the cell matrix [20].

3.4. Physicochemical Properties. Table 3 shows physicochemical properties of the G. sylvestre sauce. Tomato sauce shall not have less than $25^{\circ}$ Brix value, $4.6 \mathrm{pH}$, and $0.8 \%$ titratable acidity (SLSI Standards). The same standards were applied to $G$. sylvestre sauce when prepared. Brix value of the sauce is influenced by the presence of sugar and sweet potato flour. The FDA (approximate $\mathrm{pH}$ of food and food products 2007) has reported that the $\mathrm{pH}$ value of sauce should be within 4.4 to 5.4. According to the regulations, it is necessary to maintain the $\mathrm{pH}$ at 4.6 or less than 4.6 to preserve the product because production of botulism toxin by Clostridium botulinum is inhibited in this $\mathrm{pH}$ range [21]. Scientific report stated that acidity value is influenced by sodium benzoate, vinegar, and citric acid [21, 22].

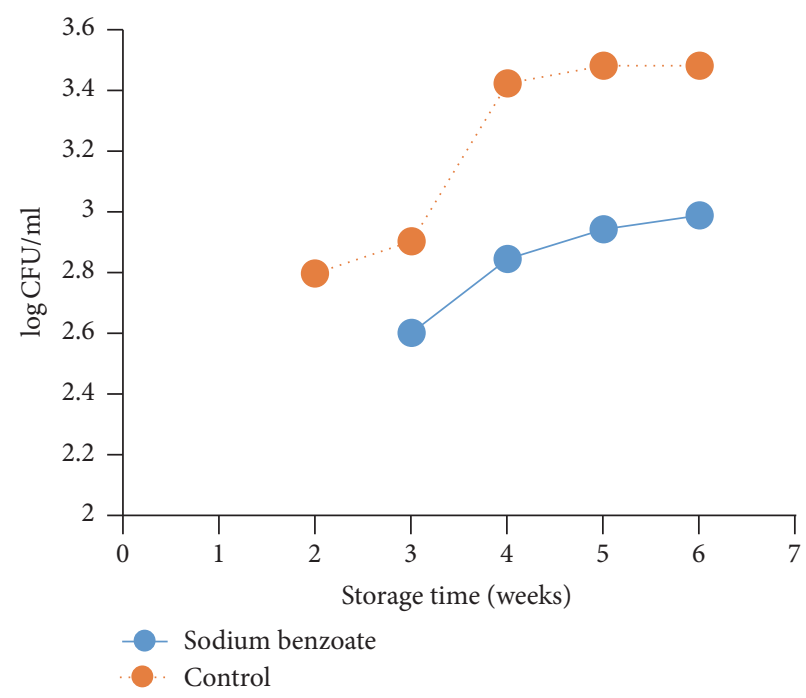

FIgURE 3: Changes of total plate count in sauce during storage.

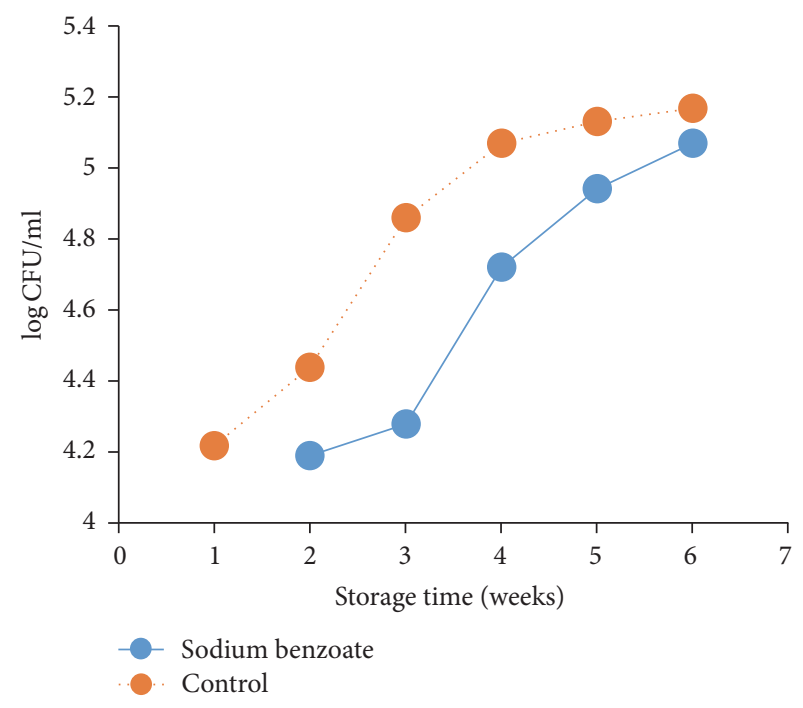

FIGURE 4: Changes of yeast and mold count in sauce during storage.

3.5. Shelf Life Evaluation. G. sylvestre sauce development study shows that there was an increasing number of bacteria, yeast, and mold growth during six weeks of storage when product was stored in sterile bottles at room temperature $\left(30 \pm 2^{\circ} \mathrm{C}\right)$, which is indicated in Figures 3 and 4 . FDA (2013) has reported that the acceptable level of yeast and mold count of sauce is $100 \mathrm{CFU} / \mathrm{g}$. Initially, sauce was free from any microbial growth. Aspergillus spp. and Penicillium spp. are those types of fungi that frequently grow on sauce compared to bacterial growth due to low $\mathrm{pH}$ because yeast and mold need acidic medium to promote the sporulation [23]. The range of acidic medium for the yeast and mold sporulation is $\mathrm{pH} 3$ and above [23]. Increasing microbial growth is due to the low heating temperature (less than $75^{\circ} \mathrm{C}$ ) applied during the preparation of sauce. Therefore, spores of microbes may be remaining after processing. If provided the favorable condition, they can accelerate their growth [24]. 
TABLE 2: The functional properties of the G. sylvestre leaf extract and sauce.

\begin{tabular}{lcc}
\hline Functional properties & Amount & Sauce \\
\hline Total antioxidant activity (\% of inhibition of DPPH) & G. sylvestre leaf extract & $43.70 \pm 0.72$ \\
Total flavonoid ( $\mu$ moles of rutin equivalent per ml of sample) & $24.15 \pm 1.48$ & $247.79 \pm 6.26$ \\
Total phenolic content $(\mu$ moles of gallic acid equivalent per ml of sample) & $52.48 \pm 0.51$ & $243.67 \pm 8.57$ \\
\hline
\end{tabular}

The values are Mean \pm SD of three independent determinations.

TABLE 3: Physicochemical properties of the sauce formulated with G. sylvestre leaves.

\begin{tabular}{lc}
\hline Properties & Value \\
\hline Total soluble solids (Brix) & $25^{\circ}$ \\
$\mathrm{pH}$ & $4.52 \pm 0.01$ \\
Titratable acidity (\% of acetic acid equivalents) & $0.82 \pm 0.11$ \\
Water activity & $0.77 \pm 0.01$ \\
\hline
\end{tabular}

The values are Mean \pm SD of three independent determinations.

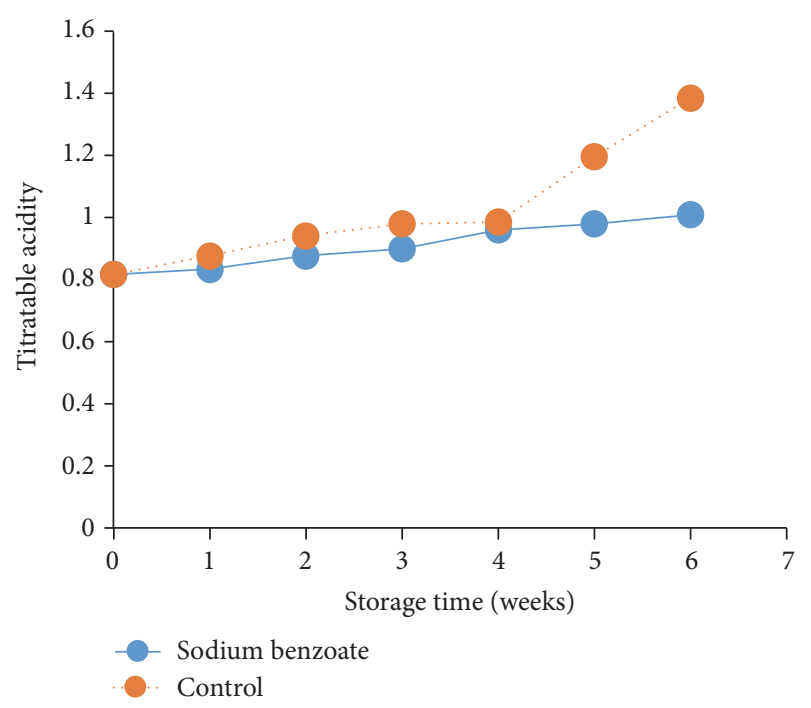

FIGURE 5: Changes of titratable acidity in sauce during storage.

At the same time, the temperature during storage will affect the growth of microorganisms because, theoretically, microorganisms grow faster at temperature of 20 to $40^{\circ} \mathrm{C}$ [24]. Another possibility for causing an increasing amount of microbial growth in sauce product is cross contamination from utensils to product or from handlers to product during handling and preparation $[21,24]$.

Increase in acidity value is due to the production of acid at low ion at low concentration during the storage, which is specified in Figure 5. Scientific report stated that this acidity value is influenced by sodium benzoate, vinegar, and citric acid added to product; increasing of acidity may result from production of acid from polysaccharide degradation and sugar oxidation or through breakdown of pectin molecule of sauce [21].

Preservatives are commonly used in almost all the processed food items in order to enhance the shelf life and maintain the product's quality. Sodium benzoate and sodium sorbate are most commonly used preservatives which are recommended by Sri Lanka Standards. In this study, usage of sodium benzoate as preservative on G. sylvestre sauce shows effectiveness in terms of bacteria, yeast, and mold retardation. Theoretically, sodium benzoate is able to retard the growth of bacteria from Bacillaceae, Enterobacteriaceae, mold, and yeast because benzoic acid is able to prevent microorganism from using substances rich in energy for their growth [25].

\section{Conclusion}

G. sylvestre leaf extract is an alternative ingredient for the production of sauce. G. sylvestre sauce has numerous health beneficial ingredients. The final sauce formulation recorded more than $70 \%$ preference for all the sensory attributes tested and it was complementary to the required Sri Lanka Standards. The sauce with $1000 \mathrm{ppm}$ sodium benzoate had six weeks of shelf life at room temperature. Further studies are needed to verify the therapeutic effect of G. sylvestre leaves after being processed into a sauce.

\section{Conflicts of Interest}

All authors declare that there are no conflicts of interest regarding the publication of this paper.

\section{References}

[1] Ashakiran and R. Deepthi, "Review article: fast foods and their impact on health," Journal of Krishna Institute of Medical Sciences University, vol. 1, no. 2, pp. 7-12, 2012.

[2] J. L. Harris, M. B. Schwartz, C. R. Munsell et al., Fast Food FACTS 2013: Measuring Progress in Nutrition and Marketing to Children and Teens, Rudd Center for Food Policy and Obesity, Hartford, Conn, USA, 2013.

[3] M. Ashwell, "Functional foods: a simple scheme for establishing the scientific validity for all claims," Public Health Nutrition, vol. 4, no. 3, pp. 859-862, 2001.

[4] A. B. A. Ahmed, A. S. Rao, and M. V. Rao, "In vitro callus and in vivo leaf extract of Gymnema sylvestre stimulate $\beta$ cells regeneration and anti-diabetic activity in Wistar rats," Phytomedicine, vol. 17, no. 13, pp. 1033-1039, 2010.

[5] G. Di Fabio, V. Romanucci, M. Zarrelli, M. Giordano, and A. Zarrelli, "C-4 gem-dimethylated oleanes of Gymnema sylvestre and their pharmacological activities," Molecules, vol. 18, no. 12, pp. 14892-14919, 2013.

[6] G. S. Thakur, R. Sharma, B. S. Sanodiya, M. Pandey, G. B. K. S. Prasad, and P. S. Bisen, "Gymnema sylvestre: an alternative 
therapeutic agent for management of diabetes," Journal of Applied Pharmaceutical Science, vol. 2, no. 12, pp. 1-6, 2012.

[7] R. B. Krishna, S. R. R. Reddy, H. Javangula, D. Swapna, and K. J. Reddy, "Isolation and characterization of gymnemic acid from Gymnema sylvestre R.Br. in control of diabetes," International Journal of Life Science and Pharmacognosy Research, vol. 2, no. 1, pp. 1-7, 2012.

[8] E. R. B. Shanmugasundaram, K. L. Gopinath, K. R. Shanmugasundaram, and V. M. Rajendran, "Possible regeneration of the islets of langerhans in streptozotocin-diabetic rats given Gymnema sylvestre leaf extracts," Journal of Ethnopharmacology, vol. 30, no. 3, pp. 265-279, 1990.

[9] A. Sanej, C. Sharma, K. R. Aneja, and R. Pahwa, "Gymnema sylvestre (Gurmar): a review," Der Pharmacia Lettre, vol. 2, no. 1, pp. 275-284, 2010.

[10] K. Bone, Clinical Applications of Ayurvedic and Chinese Herbs. Monographs for the Western Herbal Practitioner, Phytotherapy Press, Warwick, Australia, 2002.

[11] M. S. Kumar, N. Astalakshmi, P. T. Arshida et al., "A concise review on gurmar -Gymnema sylvestre R.Br," World Journal of Pharmacy and Pharmaceutical Sciences, vol. 4, no. 10, pp. 430448, 2015.

[12] AOAC, AOAC Publications of Official Testing Methods-Association of Analytical Chemists. Official Methods of Analysis, AOAC, Arlington, Va, USA, 17th edition, 2000.

[13] S. Maurya and D. Singh, "Quantitative analysis of total phenolic content in Adhatoda vasica nees extracts," International Journal of PharmTech Research, vol. 2, no. 4, pp. 2403-2406, 2010.

[14] A. A. Olajire and L. Azeez, "Total antioxidant activity, phenolic, flavonoid and ascorbic acid contents of Nigerian vegetables," African Journal of Food Science and Technology, vol. 2, no. 2, pp. 22-24, 2011.

[15] A. Arocas, T. Sanz, and S. M. Fiszman, "Improving effect of xanthan and locust bean gums on the freeze-thaw stability of white sauces made with different native starches," Food Hydrocolloids, vol. 23, no. 8, pp. 2478-2484, 2009.

[16] S. Dutta, "Sweet potatoes for diabetes mellitus: a systematic review," Pharmacophore, vol. 6, no. 1, pp. 60-72, 2015.

[17] R. Mohanraj and S. Sivasankar, "Sweet potato (Ipomoea batatas [L.] Lam) - a valuable medicinal food: a review," Journal of Medicinal Food, vol. 17, no. 7, pp. 733-741, 2014.

[18] S. Akhtar, M. Riaz, A. Ahmad, and A. Nisar, "Physico-chemical, microbiological and sensory stability of chemically preserved mango sauce and jam," Journal of Food Science, vol. 65, no. 2, pp. 718-723, 2009.

[19] A. Chandrasekara and F. Shahidi, "Content of insoluble bound phenolics in millets and their contribution to antioxidant capacity," Journal of Agricultural and Food Chemistry, vol. 58, no. 11, pp. 6706-6714, 2010.

[20] K. Bembem and B. Sadana, "Effect of cooking methods on the nutritional composition and antioxidant activity of potato tubers," International Journal of Food and Nutritional Sciences, vol. 2, no. 4, pp. 26-31, 2013.

[21] M. N. A. Rahman and N. A. M. Thajudin, "Product development of Kembayau (Canarium odontophyllum) exotic fruit sauce," Journal of Tropical Resources Sustainable Science, vol. 3, pp. 19-28, 2015.

[22] I. Hussain, A. Zeb, I. Shakir, and A. S. Shah, "Combine effect of potassium sorbate and sodium benzoate on individual and blended juices of apricot and apple fruits grown in Azad Jammu and Kashmir," Pakistan Journal of Nutrition, vol. 7, no. 1, pp. 181185, 2008.
[23] W. V. Cruess and J. H. Irish, "Further observations on the relation of $\mathrm{pH}$ value to toxicity of preservatives to microorganisms," Journal of Bacteriology, vol. 23, no. 2, pp. 163-165, 1932.

[24] O. Filtenborg, J. C. Frisvad, and U. Thrane, "Moulds in food spoilage," International Journal of Food Microbiology, vol. 33, no. 1, pp. 85-102, 1996.

[25] M. E. Otero-Losada, "Differential changes in taste perception induced by benzoic acid prickling," Physiology and Behavior, vol. 78, no. 3, pp. 415-425, 2003. 

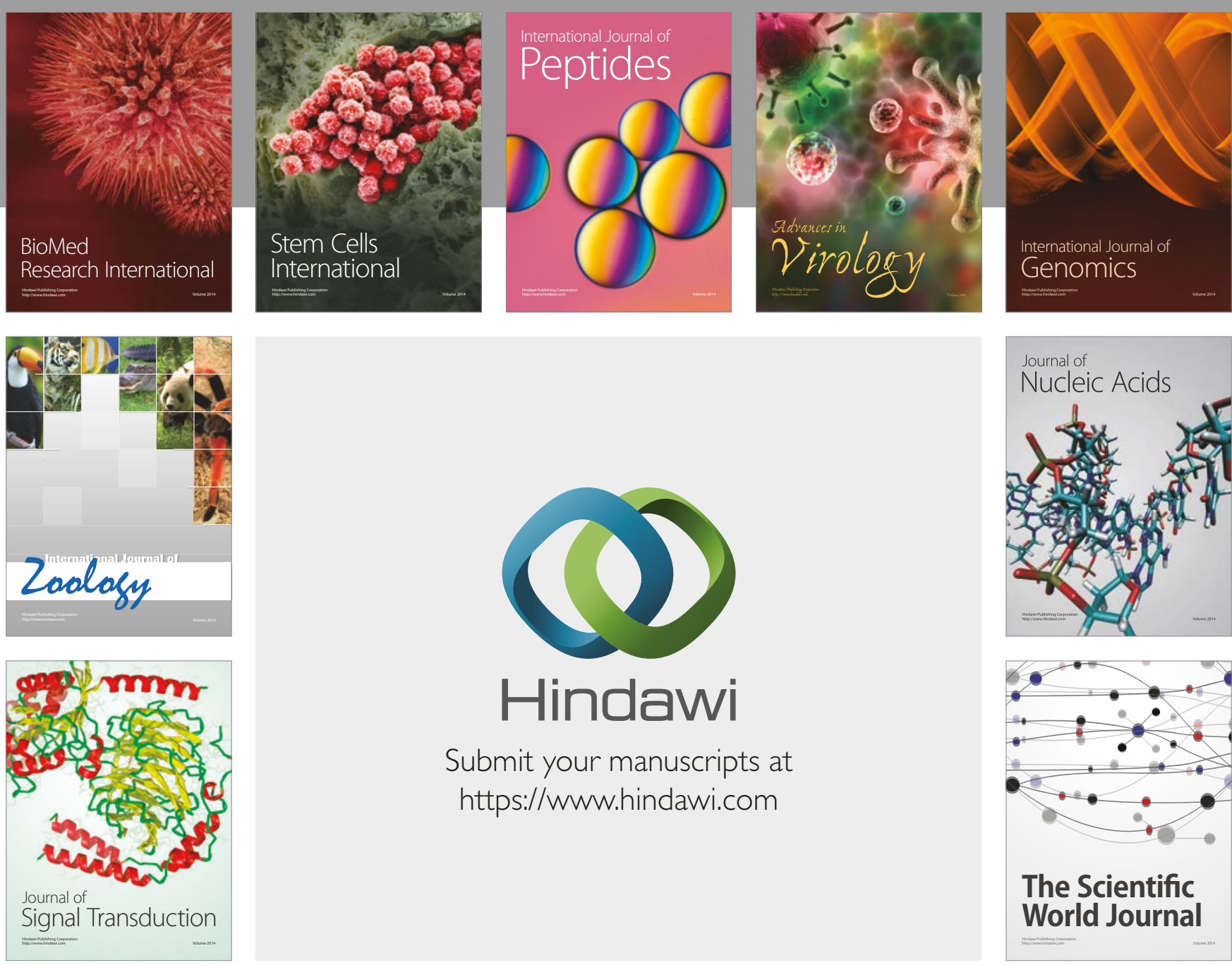

Submit your manuscripts at

https://www.hindawi.com
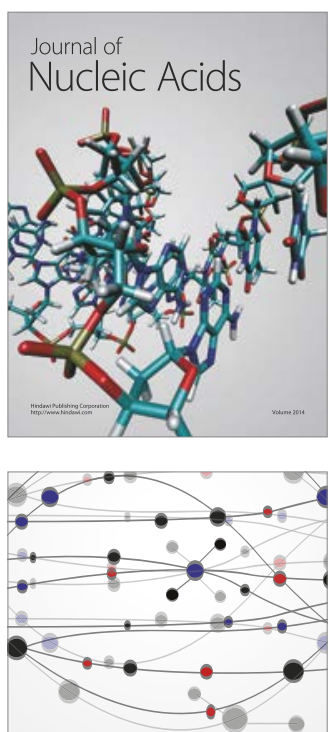

The Scientific World Journal

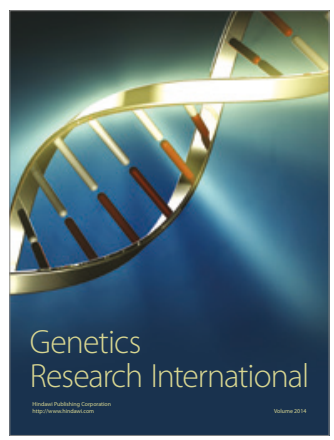

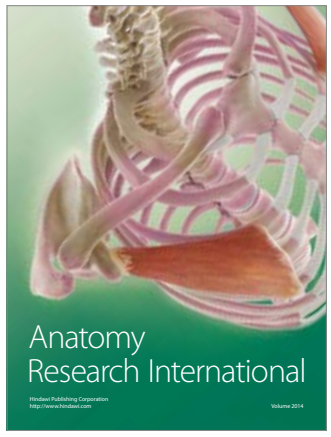

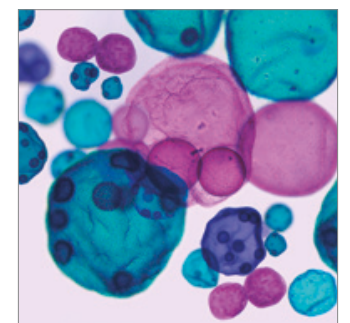

International Journal of Microbiology
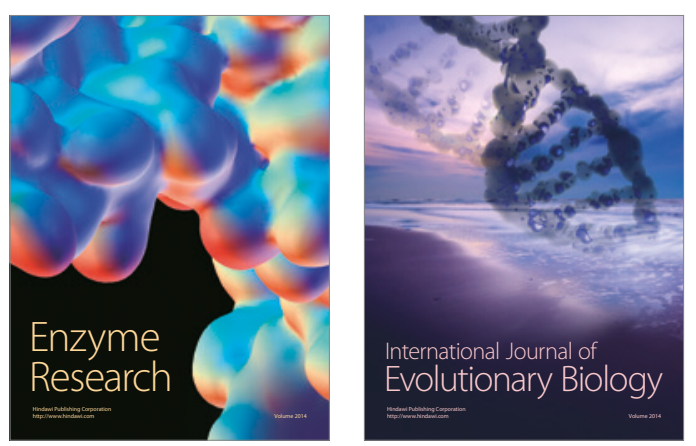
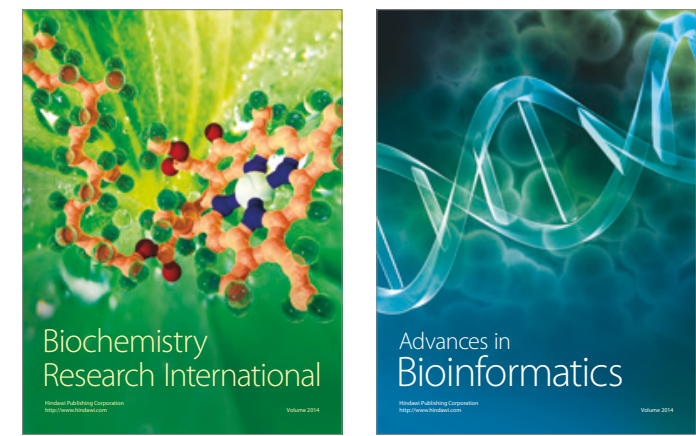

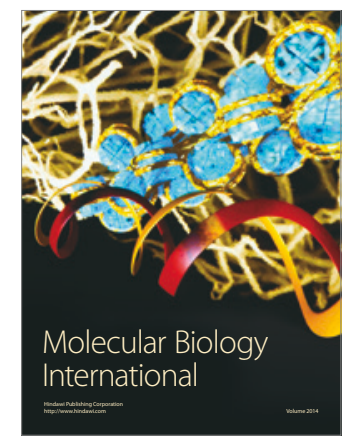

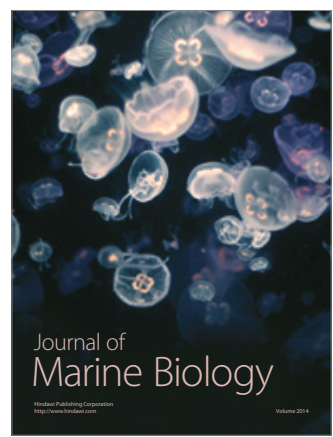

